\title{
Analysis of heat shock gene expression in Lactococcus lactis MG1363
}

\author{
José Arnau, ${ }^{1} \dagger$ Kim I. Sørensen, ${ }^{2}$ Karen F. Appel, ${ }^{1} \ddagger$ Finn K. Vogensen ${ }^{1}$ and \\ Karin Hammer ${ }^{2}$
}

Author for correspondence: José Arnau. Tel: +45 458766 99. Fax: +45 45932888.

e-mail:arnau@biobase.dk

1 Department of Dairy and Food Science, The Royal Veterinary and Agricultural University, Rolighedsvej 30, DK-1958 Frederiksberg C, Denmark

2 Department of Microbiology, Technical University of Denmark, Building 227, DK-2800 Lyngby, Denmark

\begin{abstract}
The induction of the heat shock response in Lactococcus lactis subsp. cremoris strain MG1363 was analysed at the RNA level using a novel RNA isolation procedure to prevent degradation. Cloning of the dnaJ and groEL homologues was carried out. Northern blot analysis showed a similar induction pattern for dnaK, dnaJ and groELS after transfer from $30^{\circ} \mathrm{C}$ to $43^{\circ} \mathrm{C}$ when MG1363 was grown in defined medium. The dnaK gene showed a 100-fold induction level $\mathbf{1 5} \mathbf{m i n}$ after temperature shifting. Induction of the first two genes in the dnaK operon, orf1 and grpE, resembled the pattern observed for the above genes, although maximum induction was observed earlier for orf1 and grpE. Novel transcript sizes were detected in heat-shocked cells. The induction kinetics observed for ftsH suggested a different regulation for this gene. Experimental evidence for a pronounced transcriptional regulation being involved in the heat shock response in L. lactis MG1363 is presented. A gene located downstream of the dnaK operon in strain MG1363, named orf4, was shown not to be regulated by heat shock.
\end{abstract}

Keywords: heat shock, Lactococcus lactis, stress

\section{INTRODUCTION}

Following an increase in temperature, the synthesis of a conserved set of proteins called heat shock proteins (HSPs) is induced in all living organisms, providing a means of protection against this physiological stress (Bukau, 1993; Georgopoulos \& Welch, 1993). A detailed study of the heat shock response and its regulation has been carried out in bacteria, yeast and various higher organisms (Georgopoulos \& Welch, 1993). Most HSPs are also synthesized at reduced rates in the absence of stress. In fact, HSPs have been implicated in central cellular processes such as protein renaturation, folding and degradation and DNA replication (Yura et al., 1993). In Escherichia coli and Bacillus subtilis, the induction of HSPs is obtained through alternative sigma factors, which modify the promoter recognition specificity of the RNA polymerase to enable the expression of heat shock genes (Bukau, 1993; Riethdorf et al., 1994; Schulz et al., 1995). However, in B. subtilis, a number of heat shock genes

†Present address: Biotechnological Institute, Anker Engelunds Vej 1, Building 227, DK-2800 Lyngby, Denmark.

$\ddagger$ Present address: Department of Microbiology, Technical University of Denmark, Building 227, DK-2800 Lyngby, Denmark.

Abbreviations: DEPC, diethylpyrocarbonate; HSP, heat shock protein. present a short inverted repeat element upstream from the coding region and a vegetative promoter (Zuber \& Schumann, 1994). This inverted repeat, named CIRCE, plays a role in repression under normal growth (van Asseldonk et al., 1993) and has also been found in other heat shock genes of Gram-positive bacteria including Lactococcus lactis (Kim \& Batt, 1993).

L. lactis is a common mesophilic lactic starter used in the manufacture of fermented dairy products, where bacterial growth at different limiting temperatures is often required (Auffray et al., 1992). In L. lactis, two subspecies have been defined that show different temperature ranges. Strains belonging to $L$. lactis subsp. lactis can grow at higher temperatures than strains of $L$. lactis subsp. cremoris. Recently, the model strain MG1363 has been reclassified as subsp. cremoris, based on DNA homology, despite a higher temperature optimum (Godon et al., 1992; Swindell et al., 1994). To investigate the effect of HSP induction in cheese manufacturing, we have initiated a characterization of the heat shock response in MG1363, to attempt the identification of gene(s) that allow this strain to grow at higher temperatures than other members of subsp. cremoris. Moreover, its small genome size (Le Bourgeois et al., 1995) makes $L$. lactis a very suitable organism for the study of heat shock. A number of highly 
conserved heat shock genes have been cloned from different $L$. lactis strains belonging to either subspecies (Eaton et al., 1993; Kim \& Batt, 1993; Nilsson et al., 1994; van Asseldonk et al., 1993). To date, in spite of the fact that these genes have been cloned in L. lactis, only limited efforts have been made to study the heat shock response at a molecular level.

We have developed an RNA isolation procedure that ensures no detectable degradation of samples. We are interested in the cloning and analysis of novel heat shock genes in L. lactis, using RNA subtractive hybridization. As the first step towards this goal, a study of the induction of the heat shock genes in the model $L$. lactis subsp. cremoris strain MG1363 using the corresponding genes is presented here.

\section{METHODS}

Bacterial strains, plasmids, media and growth conditions. $E$. coli XL1 Blue MRF' (Stratagene), L. lactis subsp. cremoris MG1363 (Gasson, 1983) and L. lactis subsp. lactis NCDO 2118 were used. E. coli was grown in Luria-Bertani (LB) medium. $L$. lactis was grown on minimal SA medium (Jensen \& Hammer, 1993), or on rich M17 medium (Terzaghi \& Sandine, 1975), both supplemented with $1 \%$ glucose (GSA or GM17). For the studies on heat shock, overnight cultures, grown at $30^{\circ} \mathrm{C}$ on either medium, were diluted 50 -fold in $50 \mathrm{ml}$ liquid medium and incubated at $30^{\circ} \mathrm{C}$ in a $50 \mathrm{ml}$ Erlenmeyer flask, with gentle continuous magnetic stirring, but without aeration (200 r.p.m.), to an $\mathrm{OD}_{450}$ of 0.5 . For RNA studies, heat shock was applied by shifting the cultures to $43^{\circ} \mathrm{C}$. The temperature was monitored using a digital thermometer (Ami, Germany), placing the electrode in an Erlenmeyer flask containing $50 \mathrm{ml}$ medium. A $30^{\circ} \mathrm{C}$ control sample was always included and allowed to grow for $10 \mathrm{~min}$ before collection. Samples were taken into centrifuge tubes containing liquid $\mathrm{N}_{2}$ at different times, and kept on ice. This procedure prevented freezing of the samples and RNA degradation. After centrifugation at $4{ }^{\circ} \mathrm{C}, 7000$ r.p.m. for $10 \mathrm{~min}$, the pellets were kept at $-40^{\circ} \mathrm{C}$, for RNA isolation (see below).

Plasmid pBR322 was used to construct a genomic library of strain MG1363 (see below). Plasmid pNZ2015, containing the L. lactis subsp. lactis R5 dnaJ gene (van Asseldonk et al., 1993), was kindly provided by Dr Willem M. de Vos (NIZO, Ede, The Netherlands). Plasmid pFI573 was kindly provided by $\mathrm{Dr}$ Michael Gasson (IFR Norwich, UK); it contains the dnaK operon as well as the orf 4 gene cloned from $L$. lactis subsp. cremoris MG1363 (Eaton et al., 1993). Plasmid pLN32 contains the entire $f t s H$ gene from strain MG1363 (Nilsson et al., 1994); it was a gift from Dr Dan Nilsson (CHL, Denmark).

The antibiotics used for selection were ampicillin $\left(50 \mu \mathrm{g} \mathrm{ml}^{-1}\right)$ and tetracycline $\left(12.5 \mu \mathrm{g} \mathrm{ml}^{-1}\right)$.

DNA manipulations. Chromosomal DNA from $L$. lactis was isolated as described by Johansen \& Kibenich (1992), with minor modifications. Overnight cultures $(10-50 \mathrm{ml})$ were centrifuged $\left(7000\right.$ r.p.m., $4^{\circ} \mathrm{C}$ ) for $10 \mathrm{~min}$ and the cell pellets were freeze-dried in a Heto FD-3.0 (Heto Lab Equipment, Denmark) for $12 \mathrm{~h}$. After lysozyme treatment and the addition of SDS, samples were incubated at both $37^{\circ} \mathrm{C}$ and $65^{\circ} \mathrm{C}$ for $10 \mathrm{~min}$. Plasmid DNA from E. coli was purified using Qiagen columns (Diagen). Restriction endonucleases, calf alkaline intestinal phosphatase and T4 DNA ligase were purchased from Boehringer Mannheim, New England Biolabs and Amersham, and were used as recommended by the manufacturers. All DNA manipulations were performed as described by Sambrook et al. (1989).

RNA isolation and analysis. RNA extraction was carried out using the frozen cell pellets (see above), by adding $0.7 \mathrm{~g}$ glass beads ( $150 \mu \mathrm{m}$, Sigma) and $1 \mathrm{ml}$ freshly prepared, pre-chilled RNA extraction buffer (4 M guanidine thiocyanate; $10 \mathrm{mM}$ MES pH 7.0; $10 \mathrm{mM}$ EDTA; $50 \mathrm{mM} \beta$-mercaptoethanol; $5 \%$, $\mathrm{v} / \mathrm{v}$, Triton X-100). Samples were vortexed for $30 \mathrm{~s}$ and kept on ice for at least $30 \mathrm{~s}$. This procedure was repeated a minimum of 15 times before the addition of $1 \mathrm{ml}$ phenol/chloroform $\mathrm{pH} 4.7$ (Sigma). After centrifugation at $4{ }^{\circ} \mathrm{C}, 5000$ r.p.m., for $10 \mathrm{~min}$, the aqueous phase was re-extracted with $1 \mathrm{ml}$ phenol/ chloroform and the RNA was precipitated overnight at $-40^{\circ} \mathrm{C}$, with 0.1 vol. $3 \mathrm{M}$ sodium acetate $\mathrm{pH} 5.5$ and $2.5 \mathrm{vol}$. ice-cold ethanol. Samples were centrifuged at $4{ }^{\circ} \mathrm{C}, 12000$ r.p.m., for $30 \mathrm{~min}$, then the pellets were washed in $70 \%(\mathrm{v} / \mathrm{v})$ ethanol and dried in a Hetovac (Heto Lab Equipment, Denmark). RNA was resuspended in DEPC-treated sterile water and kept at $-40^{\circ} \mathrm{C}$. All solutions, plasticware and glassware were treated with $0.1 \%$ DEPC (Sigma) overnight and autoclaved or baked at $200^{\circ} \mathrm{C}$ for $12 \mathrm{~h}$, to remove potential RNase activity. Using this protocol, undegraded RNA of high purity $\left(A_{260} / A_{280}>1.8\right)$ was routinely obtained. For analysis of transcripts, approximately $10 \mu \mathrm{g}$ RNA was denatured for $2 \mathrm{~min}$ at $100^{\circ} \mathrm{C}$ in loading buffer [ $1 \times$ MOPS buffer $(200 \mathrm{mM}$ MOPS, $50 \mathrm{mM}$ sodium acetate, $10 \mathrm{mM}$ EDTA), $50 \%(\mathrm{v} / \mathrm{v})$ formamide, $6 \%(\mathrm{v} / \mathrm{v})$ formaldehyde, $0.6 \mathrm{mg}$ ethidium bromide $\mathrm{ml}^{-1}, 5 \%(\mathrm{v} / \mathrm{v})$ glycerol] containing a 50 -fold dilution of a freshly made saturated solution of bromophenol blue in water, and separated on $1.2 \%(\mathrm{w} / \mathrm{v})$ agarose gels containing $2 \%(\mathrm{v} / \mathrm{v})$ formaldehyde in $1 \times$ MOPS buffer, at $100 \mathrm{~V}$ for $2 \mathrm{~h}$. The $0 \cdot 36-9 \cdot 49 \mathrm{~kb}$ RNA marker (Promega) was used for size determination. Gels were washed in $10 \times \operatorname{SSC}(1 \times \operatorname{SSC}$ is $1.5 \mathrm{M} \mathrm{NaCl}, 0.15 \mathrm{M}$ sodium citrate) for 30 min before transferring the RNA to GeneScreen (Du Pont) membranes by capillary blotting, overnight in $10 \times$ SSC (Sambrook et al., 1989).

Construction of a genomic library for strain MG1363. Chromosomal DNA of strain MG1363 was partially digested with Sau3AI and aliquots taken at different times were run on a $0.7 \%$ agarose gel. Samples showing an average size of $3 \mathrm{~kb}$ were used to clone into BamHI-digested, dephosphorylated pBR322. E. coli XL1-Blue MRF' (Stratagene) was transformed with the ligation mix, and filters were prepared for colony hybridization as described by Sambrook et al. (1989).

Cloning of the dnaJ gene of strain MG1363. A 726 bp internal HindIII fragment of the cloned $L$. lactis subsp. lactis strain R5 dnaJ gene (van Asseldonk et al., 1993) was used in preliminary experiments to examine the expression of the corresponding gene in strain MG1363 (Fig. 1). No hybridization was observed to heat-shocked RNA preparations, suggesting a relatively low homology. When the same fragment was used as a probe in Southern hybridizations it detected a $4.5 \mathrm{~kb}$ EcoRI DNA fragment in MG1363 only when hybridizations were carried out at low stringency, with a final $20 \mathrm{~min}$ wash at $65^{\circ} \mathrm{C}$ in $2 \times \mathrm{SSC}$, $0.1 \%$ SDS (not shown). The probe was used to screen the MG1363 genomic library and a clone, pKS2, was identified.

Amplification of the groEL gene of strain MG1363 by PCR. The sequence of the groESL operon of the L. lactis subsp. lactis strain CC9 has been reported (Kim \& Batt, 1993). Two primers, corresponding to the nucleotide positions 747-749 and 17331698 of the published sequence, within the groEL gene (Kim \& Batt, 1993), were obtained (Hobolth DNA Syntese, Denmark) and used for amplification using DNA from strain MG1363 (Fig. 1). As a control, DNA of $L$. lactis subsp. lactis strain 

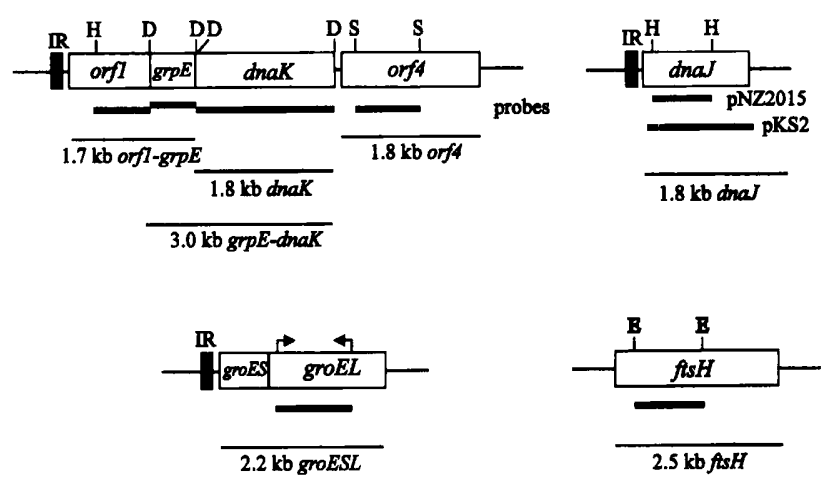

Fig. 1. Overview of heat shock genes cloned in different $L$. lactis strains, detected mRNA sizes (thin lines) and probes (thick lines) used in this study are shown (see Results). The relevant restriction sites are also depicted: D, Dral; E, EcoRV; H, HindIII; $S$, Sau3AI. IR (black boxes), inverted repeat (CIRCE) present upstream of the orf1, dnaJ and groES genes. The positions of the primers used for amplification of the groEL fragment used as a probe are indicated as arrows. The relative positions of restriction sites and primer sequences are drawn to scale according to the published sequences for the dnaK region and $\mathrm{ftsH}$ gene from $L$. lactis subsp. cremoris MG1363 (Eaton et al., 1993; Nilsson et al., 1994), and the dnaJ gene and groELS operon from $L$. lactis subsp. lactis strains R5 and CC9, respectively (van Asseldonk et al., 1993; Kim \& Batt, 1993).

NCDO 2118 was used. The reactions were carried out in a $100 \mu \mathrm{l}$ volume, using 2 units of Taq DNA polymerase (AH Diagnostics, Denmark) in a PREM thermal cycler (LEP Scientific), for 30 cycles of $92^{\circ} \mathrm{C}, 1 \mathrm{~min} ; 60^{\circ} \mathrm{C}$ (or $55^{\circ} \mathrm{C}$, see Results), $1 \mathrm{~min} ; 72^{\circ} \mathrm{C}, 2 \mathrm{~min}$. The expected $1 \mathrm{~kb}$ groEL DNA (Kim \& Batt, 1993) fragment was isolated from the gel using GeneClean (BIO101).

Northern blot analysis. Only gene-specific probes were used for Northern hybridization, as follows : a 728 bp DraI-HindIII DNA fragment from pFI573 (orf1); $586 \mathrm{bp}$ ( grpE) and $1704 \mathrm{bp}$ (dnaK) DraI DNA fragments from pFI573 (Eaton et al., 1993); an 876 bp Sau3AI DNA fragment from pFI573 (orf4) (Eaton $e t$ al., 1993); and a 1253 bp EcoRV fragment of pLN32 (fts H) (Nilsson et al., 1994). Additionally, a $1.5 \mathrm{~kb}$ Sau3AI fragment from pKS2 (dnaJ) and the amplified $1 \mathrm{~kb}$ groEL gene fragment from MG1363 were used (see above). Probes were labelled with $\left[\alpha^{32} \mathrm{P}\right] \mathrm{dATP}$, using the Multiprime DNA labelling kit (Amersham) for $2-3 \mathrm{~h}$ at $37^{\circ} \mathrm{C}$. Unincorporated nucleotides were removed using a NICK column (Pharmacia). Northern blot hybridization was carried out at $65^{\circ} \mathrm{C}$ in $0.5 \mathrm{M}$ sodium phosphate $\mathrm{pH} 7 \cdot 2,7 \%$ (w/v) SDS. Blots were washed at $65^{\circ} \mathrm{C}$ in $20 \mathrm{mM}$ sodium phosphate $\mathrm{pH} 7 \cdot 2,1 \%(\mathrm{w} / \mathrm{v}) \mathrm{SDS}$ for three periods of $15 \mathrm{~min}$.

Induction levels for dnaK and dnaJ were estimated using an Instant Imager 2024 (Packard) by measuring the radioactivity in each full-length lane directly from the nylon membrane, and normalizing to the values obtained in control samples in each case. All other induction levels were estimated by comparison.

\section{RESULTS}

\section{An RNA isolation procedure for the study of heat shock gene expression in L. lactis}

A few protocols for the study of heat shock gene expression by Northern blot analysis have been described in L. lactis (Kim \& Batt, 1993; van Asseldonk et al., 1993).
A critical step when studying the kinetics of heat shock gene expression is to ensure that samples are not exposed to additional stress during preparation, and that heat shock is homogeneously applied to a culture. We used magnetic stirring of the cultures to ensure a progressive, reproducible and fast increase in temperature without aeration. Heat shock was applied to exponentially growing cultures by shifting from $30^{\circ} \mathrm{C}$ to $43^{\circ} \mathrm{C}$. Under these conditions, and using continuous gentle agitation, a rapid increase in temperature, up to $42^{\circ} \mathrm{C}$, occurred within the first $4 \mathrm{~min}$, and the final temperature was reached after $8 \mathrm{~min}$.

Samples were mixed with liquid nitrogen and placed on ice, preventing culture freezing and RNA degradation (Fig. 2a). Consistent high yields (approx. $100 \mu \mathrm{g}$ total RNA per $50 \mathrm{ml}$ culture at $\mathrm{OD}_{450} 0.5$ ) of undegraded RNA were obtained using a protocol that omits the frequently used macaloid clay (van Asseldonk et al., 1993), which in our experience is a common source of RNase contamination. The new protocol incorporates the use of guanidine thiocyanate as a cell-disrupting agent, which is commonly used for eukaryotic RNA isolation (Sambrook et al., 1989). Analysis of electrophoretically separated RNA prepared using this method did not show any detectable degradation of the major $23 \mathrm{~S}$ and $16 \mathrm{~S} \mathrm{rRNA}$ species (Fig. 2a).

\section{Cloning of the dnaJ and groEL homologues in strain MG1363}

The use of an internal 726 bp HindIII DNA fragment of the dnaJ gene cloned from L. lactis subsp. lactis R5 (van Asseldonk et al., 1993) as a probe in Northern analysis of heat-shocked MG1363 RNA did not succeed in the detection of the corresponding dnaJ mRNA (data not shown). A relatively low homology between the dnaJ genes of these two strains could account for the lack of hybridization. Thus, a genomic library of strain MG1363 was constructed in pBR322 and approximately 2500 clones were screened with the same probe, using lowstringency hybridization. A clone, $\mathrm{pKS} 2$, was isolated and analysis of the inserted DNA showed that a $1.5 \mathrm{~kb}$ Sau3AI DNA fragment that hybridized to the above probe was present in this clone. Using the $1.5 \mathrm{~kb}$ fragment as a probe against EcoRI-digested chromosomal DNA of strain MG1363, a $4.5 \mathrm{~kb}$ fragment was detected. A similar $4.5 \mathrm{~kb}$ EcoRI DNA band was identified in low-stringency hybridization, using the HindIII fragment of the previously characterized lactococcal dnaJ gene (van Asseldonk et al., 1993), indicating that the $1.5 \mathrm{~kb}$ SauBAI fragment of pKS2 contained the homologous gene from MG1363. Subsequent sequence analysis resulted in the identification of a DNA fragment showing $85 \%$ homology to the $3^{\prime}$ end of the previously cloned L. lactis dnaJ gene (Fig. 1; data not shown). A $1 \mathrm{~kb}$ internal fragment of the groEL gene from strain MG1363 was obtained by PCR amplification using primers derived from conserved regions of the published sequence of the $L$. lactis subsp. lactis strain CC9 groESL operon (Kim \& Batt, 1993). Another L. lactis subsp. lactis strain, NCDO 2118, was used as a positive control, since a higher degree of 
(a)

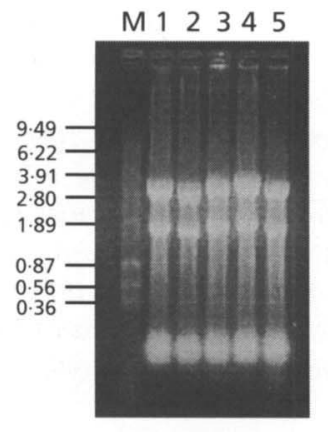

(e)

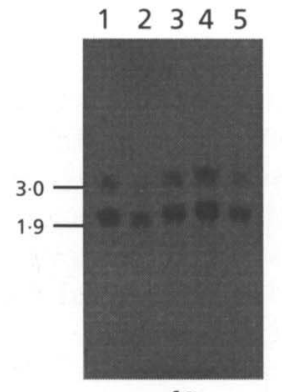

orf4 (b)

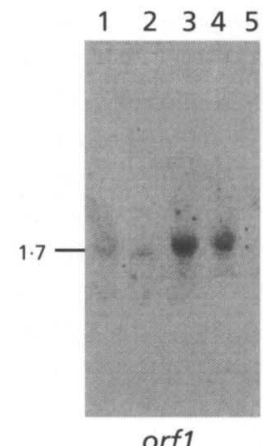

(f)

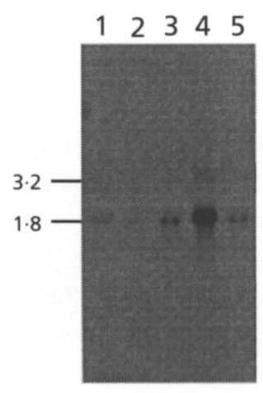

dnaJ (c)

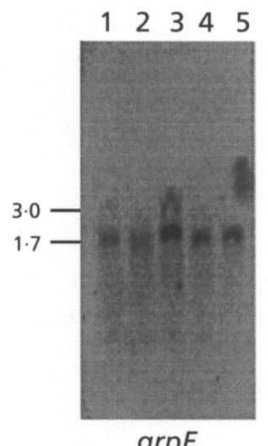

(g)

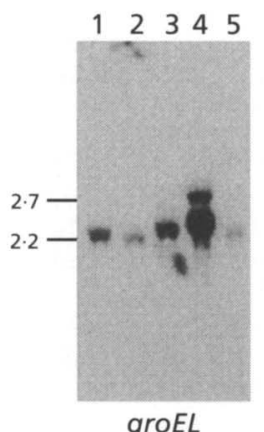

(d)

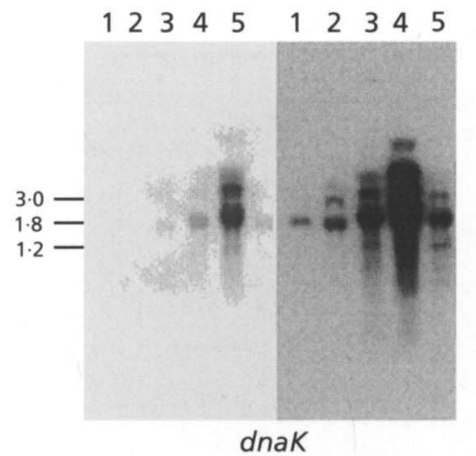

(h)

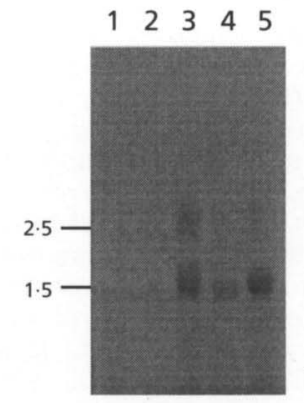

$\mathrm{ftsH}$

Fig. 2. Northern blot analysis of heat shock gene expression in strain MG1363 grown on defined, GSA medium. RNA was isolated from cells growing at $30^{\circ} \mathrm{C}$ (lanes 1 ) and at 5, 10, 15 and $20 \mathrm{~min}$ after shifting to $43^{\circ} \mathrm{C}$ (lanes $2,3,4$ and 5, respectively). Filters were hybridized with radioactively labelled gene specific probes (see Methods for details). (a) Example of RNA samples run on to a $1.2 \%(\mathrm{w} / \mathrm{v})$ agarose/formaldehyde gel. Lane $\mathrm{M}$, RNA size standards; sizes are indicated in $\mathrm{kb}$ to the left. (b-h) Northern blot hybridization, with orf1 (b), grpE (c), dnaK [exposure time: $8 \mathrm{~h}$ (left) and $48 \mathrm{~h}$ (right)] (d), orf4 (e), dnaJ ( $f)$, groEL $(\mathrm{g})$ and $\mathrm{ftsH}(\mathrm{h})$. Autoradiograms were scanned using an HP Scanjet Ilcx (Hewlett Packard) at 200 d.p.i. and assembled using Corel Draw version 5.0 software. Approximate transcript sizes are given in kb.

homology was expected between strains within this subspecies. The expected $1 \mathrm{~kb}$ DNA fragment was only amplified from strain MG1363 when an annealing temperature of $55^{\circ} \mathrm{C}$ was used, whereas the groEL gene fragment of strain NCDO 2118 was also obtained using annealing at $60^{\circ} \mathrm{C}$ (data not shown), suggesting a higher sequence homology for the groEL within subsp. lactis strains.

\section{Induction of gene expression in strain MG1363 during heat shock}

As mentioned above, no comprehensive study of the heat shock response has been reported in $L$. lactis, although a number of genes have been cloned in this organism (Eaton et al., 1993; Kim \& Batt, 1993; Nilsson et al., 1994; van Asseldonk et al., 1993).

Northern blot hybridizations were carried out on RNA isolated from strain MG1363 subjected to heat shock treatment for 5-20 min (Fig. 2). Recently, the dnaK region of strain MG1363 was cloned and sequenced. Four genes (in the order orf1-grpE-dnaK-orf4) were found (Eaton et al., 1993). Sequence analysis from this region identified a consensus promoter and a CIRCE upstream of orf1 and a transcription terminator downstream of $d n a K$, suggesting that orf1, grpE and $d n a K$ may constitute an operon. For $d n a K$, remarkably strong induction, 5-, 15- and 100-fold, respectively, 5, 10 and $15 \mathrm{~min}$ after heat shock was observed and a significantly higher level of expression (10-fold) was detected even after $20 \mathrm{~min}$, as compared to control cells (Fig. 2d). A $1.8 \mathrm{~kb}$ transcript was observed in all samples which corresponds in size to the dnaK gene. Interestingly, no promoter sequence was reported upstream of this gene (Eaton et al., 1993). A larger transcript $(3.0 \mathrm{~kb})$ which may include at least $g r p E$ (see below) was only observed in heat-shocked cells, together with a $1 \cdot 2 \mathrm{~kb}$ mRNA (Fig. 2d).

In many bacteria, the dnaJ gene is found in the same operon as grpE and dnaK (Eaton $e t$ al., 1993). However, in $L$. lactis, the dnaJ gene has been reported to be transcribed independently and to include a CIRCE upstream of the promoter sequence (van Asseldonk et al., 1993). Using the MG1363 dna J gene, a low level of expression was observed in control cells (Fig. 2f, lane 1) and at least a 2 - and 10 -fold induction was found after 10 and $15 \mathrm{~min}$ at $43^{\circ} \mathrm{C}$, respectively (Fig. 2f, lanes $2-4$ ). A $1.8 \mathrm{~kb}$ mRNA was observed in all samples, in agreement with the published Northern blot analysis of the L. lactis subsp. lactis strain 
R5 dnaJ gene (van Asseldonk et al., 1993), and a faint $3.2 \mathrm{~kb}$ band was only detected after 15 min (Fig. 2f, lane 4). No smaller transcripts were detected, in contrast to a $1.0 \mathrm{~kb}$ mRNA reported to hybridize to dna and to be a specific breakdown product of the $1.8 \mathrm{~kb}$ RNA species (van Asseldonk et al., 1993).

The groESL operon was cloned in L. lactis subsp. lactis CC9. A CIRCE was also found upstream of the groES gene (Kim \& Batt, 1993). Using the groEL probe (Fig. 1), a major $2 \cdot 2 \mathrm{~kb}$ transcript showed a 10 -fold induction after $15 \mathrm{~min}$ (Fig. $2 \mathrm{~g}$ ). This may also include the groES mRNA, as reported for E. coli and Agrobacterium tumefaciens (Segal \& Ron, 1995). The general induction pattern showed similar kinetics for dnaK, dnaJ and groEL, with an increasing level of mRNA up to 15 min after heat shock, and a decrease observed after $20 \mathrm{~min}$ (Fig. $2 \mathrm{~d}, \mathrm{f}$ and g). In contrast to the situation for all other genes studied, a lower level of groEL mRNA was observed after $20 \mathrm{~min}$ compared to control cells (Fig. 2g, lanes 1 and 5), suggesting a tight control of expression for this gene in heat-shocked cells. An additional $2.7 \mathrm{~kb}$ transcript was only detected after $15 \mathrm{~min}$ (Fig. $2 \mathrm{~g}$, lane 4).

The first gene in the L. lactis dnaK operon (Fig. 1), orf1, showed homology to the first gene in the dnaK operon of other Gram-positive bacteria and has been proposed to have a regulatory role (Eaton et al., 1993; Naberhaus et al., 1992; Schulz et al., 1995; Wetzstein et al., 1992). The order of the first three genes (orf1-grpE-dnaK) is conserved among this group of bacteria (Naberhaus et al., 1992; Wetzstein $e t$ al., 1992). At least a fivefold induction of orf 1 was observed after $10 \mathrm{~min}$ at $43^{\circ} \mathrm{C}$, and a low level of orf 1 mRNA was observed in control cells and after $20 \mathrm{~min}$ at $43^{\circ} \mathrm{C}$ (Fig. 2b, lanes 3 and 5).

The $g r p E$ probe identified two mRNA species. A $1.7 \mathrm{~kb}$ mRNA, present at a low level in control cells, showed at least a fivefold induction after $10 \mathrm{~min}$ and decreased to normal levels after $20 \mathrm{~min}$ (Fig. 2c). An additional band, approximately $3.0 \mathrm{~kb}$ in size, was only observed after $10 \mathrm{~min}$ (Fig. 2c, lane 3). The grpE gene is located immediately downstream of the orf1 gene in strain MG1363 (Fig. 1), and no transcription terminator sequence was found in the intergenic region (Eaton et al., 1993). Since a similar-sized mRNA hybridized to the orf 1 and $g r p E$ probes, and the induction of both genes occurred at identical times, the two genes may be co-transcribed. The size of this RNA species, $1.7 \mathrm{~kb}$ (Fig. 1, Fig. 2b, c), correlated well with the DNA region including both genes (Eaton et al., 1993). The size of the chromosomal region including orf1, grpE and $d n a K$ in strain MG1363 is about $3.5 \mathrm{~kb}$. No transcript of this size was detected with either gene probe.

A novel gene which codes for a protein of unknown function, orf4, was found downstream of the dnaK gene in strain MG1363 (Eaton et al., 1993). Northern blot hybridization was carried out to study the expression of this gene during heat shock. Two transcripts $(3.0$ and $1.9 \mathrm{~kb}$ ) were detected at similar levels in control and heatshocked samples (Fig. 2e). Thus, expression of orf4 was not induced by heat shock in defined medium. No expression of orf4 was detected when cells were grown in GM17 medium, regardless of the temperature, suggesting that this gene is not essential when growing in rich medium (data not shown). Interestingly, lower levels of orf $4 \mathrm{mRNA}$ were found after 5 and $20 \mathrm{~min}$, especially for the larger transcript. A similar situation was observed for the majority of genes studied (Fig. 2). Independent RNA samples and hybridization experiments were carried out to confirm that the difference in intensity of these bands was not due to different amounts of RNA being loaded, or to unspecific degradation (Fig. 2a, e).

The B. subtilis $f t s H$ gene is induced after heat shock, despite the lack of CIRCE (Schulz et al., 1995). The $L$. lactis fts $H$ gene was cloned from strain MG1363 and no CIRCE was found in the promoter region of this gene. A mutant carrying a truncated $f t s H$ gene showed increased thermosensitivity, suggesting a role in heat shock (Nilsson et al., 1994). Using the fts $H$ probe, a $2.5 \mathrm{~kb} \mathrm{mRNA}$, corresponding to the size of the fts $H$ gene (Fig. 1), was detected at very low levels only $10 \mathrm{~min}$ after temperature shift (Fig. 2h, lane 3). A smaller, $1.5 \mathrm{~kb}$ band was also observed after 10,15 and $20 \mathrm{~min}$; this may be a specific breakdown product of the $2.5 \mathrm{~kb}$ mRNA (Fig. $2 \mathrm{~h}$, lanes 3-5). A similar induction pattern was also observed when cells were grown in rich GM17 medium (data not shown).

Remarkably, lower levels of mRNA were observed after $5 \mathrm{~min}$ for all genes studied than in control cells, with the sole exception of $d n a K$. This included the constitutively expressed gene orf4, and was observed in duplicate experiments using independent RNA samples.

\section{DISCUSSION}

We have studied heat shock gene expression in L. lactis subsp. cremoris MG1363 growing in defined medium. In our conditions, a rapid increase in temperature occurs and cells are only subjected to heat stress. A new RNA isolation method allowed the study of the kinetics of induction during the first $20 \mathrm{~min}$ after temperature shift. The induction of gene expression after temperature shift from $30^{\circ} \mathrm{C}$ to $43^{\circ} \mathrm{C}$ was studied by Northern blot hybridization using gene-specific probes.

The known heat shock genes dnaK, dnaJ and groEL, as well as members of the suggested dnaK operon and $f t s H$, all showed induction of the corresponding $\mathrm{mRNA}(\mathrm{s})$, providing experimental evidence for a transcriptional regulation of the heat shock response in L. lactis, as shown for E. coli and B. subtilis (Bukau, 1993; Schulz et al., 1995). For dnaJ, groEL and dnaK, a high level of induction was observed, ranging from 10 - (dnaJ and groEL) to 100 -fold $(d n a K)$. The induction pattern for these three genes was similar, with an increasing level of mRNA up to $15 \mathrm{~min}$ after heat shock and a reduction observed after $20 \mathrm{~min}$. This correlates with the presence of a CIRCE upstream of these genes.

A slightly different pattern was detected for orf1 and $g r p E$. Maximum induction was reached already after $10 \mathrm{~min}$ and 
was still maintained after $15 \mathrm{~min}$. A regulatory function has been proposed for these two genes in other bacteria (Bukau, 1993; Schulz et al., 1995), which may account for this difference.

The $f t s H$ gene codes for a membrane-bound ATPdependent protease involved in many cellular processes, such as cell division, protein translocation and regulation of gene expression in E. coli (Akiyama et al., 1994; Herman et al., 1993; Ogura et al., 1991). As in B. subtilis, the $L$. lactis $f t s H$ gene was shown to affect temperature sensitivity, suggesting a role in heat shock, although no CIRCE was found in the promoter region of this gene (Schulz et al., 1995; Nilsson et al., 1994). To our knowledge, the expression of $f t s \mathrm{H}$ has been exclusively studied at the protein level, and no Northern blot hybridization has been included in any of the organisms where the gene has been cloned. The induction of this gene under heat shock followed a different kinetics, with a significant induction after $10 \mathrm{~min}$ that was still observed after $20 \mathrm{~min}$ (Fig. 2h). An alternative regulatory mechanism for heat shock genes lacking a CIRCE may be responsible for the differences observed.

No induction was observed for orf 4 in defined medium (Fig. 2e). A transcription terminator sequence located downstream from the adjacent $d n a K$ gene and a vegetative promoter were found upstream of the orf 4 coding region. Interestingly, no expression was detected in GM17 in either control or heat-shocked cells (data not shown).

Assuming that a full-length transcript of the dnaK operon is efficiently processed in $L$. lactis, our results are consistent with the analysis of the reported DNA sequence, where a consensus vegetative promoter and a CIRCE were found upstream of orf1 and a terminator structure separated dnaK from orf4 (Eaton $e t$ al., 1993). The major processing products include a monocistronic dnaK mRNA, and two bicistronic mRNA species (orf1$g r p E$ and $\operatorname{grp} E-d n a K)$. However, further experiments on the regulation of the $d n a K$ operon are required to confirm the suggested processing.

The groEL gene was found to be expressed in control samples grown at $30^{\circ} \mathrm{C}$ in GSA (Fig. $2 \mathrm{~g}$ ), in contrast to the published results (Kim \& Batt, 1993). Our results, which included a control experiment where heat shock was applied to cells growing in rich, GM17 medium (data not shown), are consistent with the observation that this gene is essential at all temperatures in both $E$. coli and $B$. subtilis (Burnett et al., 1994; Kanemori et al., 1994; Schmidt et al., 1992).

The expression of heat shock genes was also studied in rich medium. Generally, lower and faster induction levels were observed for all genes studied except $f t s H$ (data not shown).

The procedure described here for the study of heat shock gene expression in L. lactis allowed the detection of highly induced levels of mRNA for the genes known to be involved in the heat shock response. A significant difference in expression level between the induced and non-induced state is advantageous for the cloning of novel heat shock genes. We are currently using RNA subtractive hybridization to attempt the cloning of such genes.

\section{ACKNOWLEDGEMENTS}

This work was supported by the FØTEK program as a collaboration between the Danish Center for Lactic Acid Bacteria and the MFF (Danish Dairy Research Board). We thank Dr Mogens Kilstrup (Technical University of Denmark) for critical suggestions and quantification of Northern blots.

\section{REFERENCES}

Akiyama, Y., Shirai, Y. \& Ito, K. (1994). Involvement of FtsH in protein assembly into and through the membrane. II. Dominant mutations affecting FtsH functions. J Biol Chem 269, 5225-5229.

van Asseldonk, M., Simons, A., Visser, H., De Vos, W. M. \& Simons, G. (1993). Cloning, nucleotide sequence and regulatory analysis of the Lactococcus lactis dnaJ gene. J Bacteriol 175, 1637-1644.

Auffray, Y., Gansel, X., Thammavongs, B. \& Boutibonnes, P. (1992). Heat shock-induced protein synthesis in Lactococcus lactis subsp. lactis. Curr Microbiol 24, 281-284.

Bukau, B. (1993). Regulation of the Escherichia coli heat shock response. Mol Microbiol 9, 671-680.

Burnett, B. P., Horwich, A. L. \& Low, K. B. (1994). A carboxyterminal deletion impairs the assembly of GroEL and confers a pleiotropic phenotype in Escherichia coli K-12. J Bacteriol 176, 6980-6985.

Eaton, T., Shearman, C. \& Gasson, M. (1993). Cloning and sequencing analysis of the $d_{n a K}$ gene region of Lactococcus lactis subsp. lactis. J Gen Microbiol 139, 3253-3264.

Gasson, M. (1983). Plasmid complements of Streptococcus lactis NCDO712 and other lactic streptococci after protoplast-induced curing. J Bacteriol 154, 1-9.

Georgopoulos, C. \& Welch, W. J. (1993). Role of the major heat shock proteins as molecular chaperones. Annu Rev Cell Biol 9, 601-634.

Godon, J. J., Delorme, C., Ehrlich, S. D. \& Renault, P. (1992). Divergence of genomic sequences between Lactococcus lactis subsp. lactis and Lactococcus lactis subsp. cremoris. Appl Environ Microbiol 58, 4045-4047.

Herman, C., Ogura, T., Tomoyasu, T., Hiraga, S., Akiyama, Y., Ito, K., Thomas, R., D'Ari, R. \& Bouloc, P. (1993). Cell growth and $\lambda$ phage development controlled by the same essential Escherichia coli gene, ftsH/HfB. Proc Natl Acad Sci USA 90, 10861-10865.

Jensen, P. R. \& Hammer, K. (1993). Minimal requirements for exponential growth of Lactococcus lactis. Appl Environ Microbiol 59, 4363-4366.

Johansen, E. \& Kibenich, A. (1992). Characterization of Leuconostoc isolates from commercial mixed strain mesophilic starter cultures. $J$ Dairy Sci 75, 1186-1191.

Kanemori, M., Mori, H. \& Yura, T. (1994). Effects of reduced levels of $\mathrm{GroE}$ chaperones in protein metabolism: enhanced synthesis of heat shock proteins during steady-state growth of Escherichia coli. $J$ Bacteriol 176, 4235-4242.

Kim, S. G. \& Batt, C. A. (1993). Cloning and sequencing of the Lactococcus lactis subsp. lactis groESL operon. Gene 127, 121-126.

Le Bourgeois, P., Lautier, M., van den Berghe, L., Gasson, M. J. \& Ritzenthaler, P. (1995). Physical and genetic map of the Lactococcus 
lactis subsp. cremoris MG1363 chromosome: comparison with that of Lactococcus lactis subsp. lactis IL1403 reveals a large genome inversion. J Bacteriol 177, 2840-2850.

Naberhaus, F., Giebeler, K. \& Bahl, H. (1992). Molecular characterization of the dnaK gene region of Clostridium acetobutylicum, including grpE, dnaJ, and a new heat shock gene. $J$ Bacteriol 174, 3290-3299.

Nilsson, D., Lauridsen, A. A., Tomoyasu, T. \& Ogura, T. (1994). A Lactococcus lactis gene encodes a membrane protein with putative ATPase activity that is homologous to the essential Escherichia coli ftsH gene. Microbiology 140, 2601-2610.

Ogura, T., Tomoyasu, T., Yuki, T., Morimura, S., Beggs, K. J., Donachie, W. D., Mori, H., Niki, H. \& Hiraga, S. (1991). Structure and function of the $f t s H$ gene. Res Microbiol 142, 279-282.

Riethdorf, S., Völker, U., Gerth, U., Winkler, A., Engelmann, S. \& Hecker, M. (1994). Cloning, nucleotide sequence and expression of the Bacillus subtilis lon gene. J Bacteriol 176, 6518-6527.

Sambrook, J., Fritsch, E. F. \& Maniatis, T. (1989). Molecular Cloning: a Laboratory Manual, 2nd edn. Cold Spring Harbor, NY: Cold Spring Harbor Laboratory.

Schmidt, A., Schiesswohl, M., Völker, U., Hecker, M. \& Schumann, W. (1992). Cloning, sequencing, mapping and transcriptional analysis of the groESL operon from Bacillus subtilis. J Bacteriol 174, 3993-3999.
Schulz, A., Tzschaschel, B. \& Schumann, W. (1995). Isolation and analysis of the dnaK operon of Bacillus subtilis. Mol Microbiol 15, 421-429.

Segal, G. \& Ron, E. Z. (1995). The groESL operon of Agrobacterium tumefaciens: evidence for heat shock-dependent mRNA cleavage. $J$ Bacteriol 177, 750-757.

Swindell, S. R., Griffin, H. G. \& Gasson, M. (1994). Cloning, sequencing and comparison of three lactococcal L-lactate dehydrogenase genes. Microbiology 140, 1301-1305.

Terzaghi, B. E. \& Sandine, W. E. (1975). Improved medium for lactic streptococci and their bacteriophages. Appl Microbiol 29, 807-813.

Wetzstein, M., Völker, U., Dedio, J., Lobbau, S., Zuber, U., Schiesswohl, M., Herget, C., Hecker, M. \& Schumann, W. (1992). Cloning, sequencing and molecular analysis of the dnaK locus from Bacillus subtilis. J Bacteriol 174, 3300-3310.

Yura, T., Nagai, H. \& Mori, H. (1993). Regulation of the heat-shock response in bacteria. Annu Rev Microbiol 47, 321-350.

Zuber, U. \& Schumann, W. (1994). CIRCE, a novel heat shock element involved in regulation of heat shock operon $d n a K$ of Bacillus subtilis. J Bacteriol 176, 1359-1363.

Received 25 September 1995; revised 11 January 1996; accepted 23 February 1996. 